\title{
The role of organizational learning in transformational leadership and organizational innovation
}

\author{
Hsi-Chi Hsiao $\cdot$ Jen-Chia Chang
}

Received: 13 May 2010/ Accepted: 11 April 2011/Published online: 27 April 2011

(C) The Author(s) 2011. This article is published with open access at Springerlink.com

\begin{abstract}
Leadership is an important factor affecting organizational innovation. Many studies show that transformational leadership has positive and significant influence on organizational innovation. Based on a literature review and previous work, this study aims to investigate the influence of transformational leadership on organizational innovation and to examine whether organizational learning is a mediator between their relationships. Structural equation modeling was used to test the model. The research sample consisted of 330 teachers in charge of administration in postsecondary schools. The findings of this study provide evidence that transformational leadership and organizational learning have significant positive relationship influence on organizational innovation. The research also demonstrates that there is significant effect on the role of mediation in organizational learning on the relationship between transformational leadership and organizational innovation. The study suggests that if school principals use the strategies of transformational leadership and organizational learning at the same time, organizational learning was highly effectiveness to achieve organizational innovation in the postsecondary schools.
\end{abstract}

Keywords Transformational leadership - Organizational innovation · Organizational learning

H.-C. Hsiao

Graduate Institute of Business and Management, Cheng Shiu

University, Kaohsiung, Taiwan

J.-C. Chang ( $\square)$

Institute of Technological and Vocational Education, National

Taipei University of Technology, Box 4037, 1, Sec. 3,

Chung-hsiao E. Rd., Taipei, Taiwan

e-mail: jc5839@ntut.edu.tw

\section{Introduction}

Innovation through creativity is an important factor for the success and competitive advantage of organizations (Woodman et al. 1993). Most school organizations are facing a dynamic environment characterized by rapid social changes, educational policies, and globalization. In particular, Taiwan faces the impact of open enrollment, school choice, and a baby bust. All these bring many challenges for school organizations. Schools need to be more creative and innovative in order to compete, to grow, and to lead. Helping students perform in the realm of creative behavior requires changes in both educational policy and teaching practices (ChanLin et al. 2006). The Ministry of Education in Taiwan has made great changes in curricula and has reformed teaching methods. Students are required to learn in a diversified, autonomous, and flexible setting (Ministry of Education 2003). The school leaders are providing inspiration and motivation for teachers, and teachers are introducing more innovative activities into their classrooms.

Leadership has become recognized as the presence of followership (Robbins and Judge 2009). Leadership provides meaning for those within an institution by defining and espousing the values of the organization (Fidler 2003). Successful organizations require both leadership and management but these need not necessarily be combined in one person. Both leadership and management can be dispersed within an organization (Fidler 2003). There is evidence that supportive leadership is positively associated with organizational learning (Lei et al. 1999; Montes et al. 2005; Swiering and Wierdsma 1992; Tushman and Nadler 1986) and innovation (Montes et al. 2005). This support leadership enables the building of teams and provides them with direction, energy, and support for processes of change 
and increased cohesion (Tushman and Nadler 1986). School leaders are encouraged to use a range of activities and diverse management strategies to facilitate innovation in teachers (ChanLin et al. 2006).

Most studies indicated that organizational learning injects new ideas into the organization. This increases the capacity of teachers to spot new opportunities, understand new ideas, and strengthen their creativity (Hsiao et al. 2009). Organizational learning leads to innovation. The arguments address the premise that learning and innovation are coincident. In addition, there is a lack of studies that examine how transformational leadership affects innovation through the use of organizational learning, which in itself plays an important role in promoting the innovation process in an organization.

Louis (2006) suggested that the capacity for innovation and reform in a school depended on its ability to collectively process, understand, and apply knowledge about teaching and learning. This was criticized by Spender and Grant (1996) who implied there was overemphasis in schools on what should be learned, rather than on the processes of knowledge acquisition, creation, dissemination, and integration. Argyris and Schön (1978) held that organizational learning would enhance the innovative capacity of an organization. In other words, organizational learning can be an important role for organizational innovation. Most studies of organizational learning associated it with organizational innovation (Hsiao et al. 2009; Weerawardena et al. 2006).

Every innovative organization exerts great effort in the creation of an environment that will allow freedom and flexibility in their overall strategic direction (Hecker and Birla 2008). Leaders must play an active role in the process. Leaders should inspire their employees to develop creativity, stimulate their minds, and show concern for individuals (Bass and Avolio 2006). Several studies reveal that increased team learning leads to increased organizational innovation (Lloréns Montes et al. 2005), and this can inspire the research team (Webber and Donahue 2001; Michael et al. 2004) and promote organizational learning (García-Morales et al. 2006). These are some of the traditional factors that contribute to organizational innovation. This study is meant to serve as a preliminary model and a guide to explain how transformational leadership and organizational learning can affect innovation.

A further purpose was to examine how transformational leadership positively relates to organizational innovation and a model is proposed (see Fig. 1). Transformational leadership positively relates to organizational learning. Organizational learning positively relates to organizational innovation. Organizational learning mediates the relationship between transformational leadership and organizational innovation.

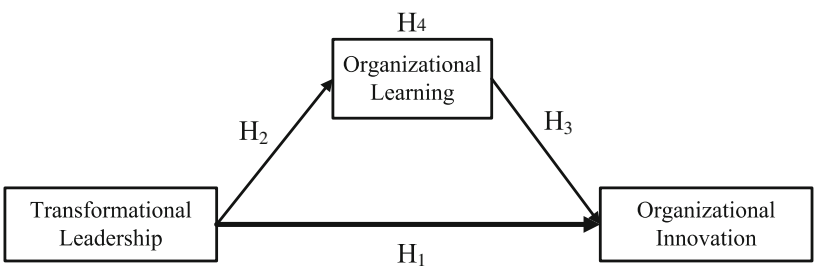

Fig. 1 The conceptual model

\section{Theoretical background and hypotheses}

The relationship between transformational leadership and organizational innovation

Several studies indicated that transformational leaders empower (Jung and Sosik 2002) and provide an innovative climate for their followers (Jung et al. 2003). Gumusluoglu and Ilsev (2009) found that the role of transformational leaders enhanced organizational innovation. Jung et al. (2003) who studied 32 Taiwanese companies found that there was a positive relationship between transformational leadership and organizational innovation. It is important for leaders to use inspirational motivation and intellectual stimulation for organizational innovation (Elkins and Keller 2003).

Transformational leaders may also have a positive influence on the market success of innovation (Gumusluoglu and Ilsev 2008). Leaders who articulate a strong vision of innovation and display a sense of power and confidence will strive to ensure the market success of innovation and mobilize their followers to ensure this (Jung et al. 2003). Leading professional employees might require more than traditional leadership skills especially in R\&D settings where quality rather than quantity is the primary performance criterion (Keller 1992). Furthermore, in addition to an internal role, the transformational leader may be effective in external roles such as boundary spanning and championing (Howell and Higgins 1990); these might be important both for understanding the needs of the market and for successful marketing of the innovation. Therefore, this study proposes a positive relationship between transformational leadership and organizational innovation which is conceptualized in this paper as including both the tendency of the organization to innovate and the success of innovations. Thus,

Hypothesis 1 Transformational leadership will have a positive effect on organizational innovation.

The relationship between transformational leadership and organizational learning

Several studies have shown that there is a significant relationship between transformational leadership and 
organizational learning (Senge 1990; Slater and Narver 1995; Silins et al. 2002). Hsiao et al. (2008) have defined transformational leaders as those who employ extraordinary influence over people to transform the notions and attitudes of organization members. This is a process initiating a single focus and willingness to act in the best interests of the organization that prompts transformation and reform. The transformational leadership factors include: idealized influence-attributes, idealized influencebehavior, inspirational motivation, intellectual stimulation, and individualized consideration (Bass and Avolio 2006).

Kark et al. (2003) suggest that transformational leadership influences followers by connecting their concept of self to the mission of the organization or group and by addressing and modifying their values and self-esteem. Transformational leaders influence followers by shifting goals away from personal interest toward self-actualization and the greater good. Followers are motivated by a fear of disappointing the leader (Chen 2002; Yukl 2002). Transformational leaders can create conditions in the organization which support and sustain the performance of the administrators, teachers, and students. This set of practices acknowledges the importance of collective or organizational learning. The building of professional learning is a key contribution to the teachers work and the students' learning (Davies 2005). The transformational style of administration allows the organization to learn through experimentation, communication, and dialogue (McGill and Slocum 1993). It also encourages the stimulation, individualized consideration, and motivation essential to learning (Sarros et al. 2002). Thus, we propose,

Hypothesis 2 Transformational leadership will have a positive effect on organizational learning.

The relationship between organizational learning and organizational innovation

The literature on organizational innovation has received important contributions from that on organizational learning. These contributions show a positive relationship between organizational learning and innovation (Aragón-Correa et al. 2007; Gerybadze and Reger 1999; Gumusluoglu and Ilsev 2009; Lloréns-Montes et al. 2005; McKee 1992). In the organization studied the leader focuses on creating a context favorable to innovation and organizational learning. Leaders can do much to prepare the "mind" of their organization. Innovation is not an individual action but a collective achievement. García-Morales et al. (2008) proposed that organizational learning and innovation should be stimulated to drive performance. In other words, organizational innovation depends on organizational learning (Cohen and Levinthal 1990). Therefore, this study proposes,
Hypothesis 3 Organizational learning has a positive effect on organizational innovation.

The main purpose of this study is to determine whether teachers in charge of administration duties have perceptions of organizational learning. Perceptions of attraction of team members and team spirit are the mechanisms that underlie and mediate effects between transformational leadership and organizational innovation. In order to examine the impact of different individual variables to organizational innovation, this study also estimates the direct and indirect influence of innovation on transformational leadership. Therefore, this study proposes,

Hypothesis 4 Organizational learning will be a mediator between transformational leadership and organizational innovation.

\section{Method}

\section{Sample}

Empirical research was used in this study to explore how organizational learning mediates the relationship between transformational leadership and organizational innovation. Thirty-six postsecondary schools in Taiwan were selected with a stratified random sampling method. And of teachers in charge of administration in these schools, a total of 330 samples participated in the current study. The average age was 32 years $(\mathrm{SD}=10$ years $)$ with a range of $32-50$ years, and 185 were men $(56.06 \%)$ and 145 were women $(43.94 \%)$. The average tenure at the school was 12 years. The sample group was highly educated: Bachelors 50.4\%; Masters 48\%; PhDs 1.8\%; $24.1 \%$ were department heads, $47.7 \%$ were division directors, and $28.2 \%$ were vice-directors. Locations of the schools were as follows: $50.0 \%$ in Northern Taiwan; $12.7 \%$ in Eastern Taiwan; $29.7 \%$ in Central Taiwan; and the remainder in the South.

\section{Procedures}

Based on a review of the literature and previous research, four hypotheses were formulated and examined. The questionnaires were given to the participants during working hours, and all participants received the same questionnaire comprising two sections. The first consisted of demographic information, but the second was more specific. This section, consisting of 32 items, had 20 about transformational leadership, 7 about organizational learning, and 5 about organizational innovation. All were composed of 5-point scaled Likert-type items. The average time for completion of each questionnaire was $25-30 \mathrm{~min}$. 


\section{Measures}

For the purpose of this study, we first constructed a measurement model using all the survey items to test the psychometric properties of the scales. Table 1 shows the index of confirmatory factor analysis in three scales. The average variance extracted (AVE) as suggested by Fornell and Larcker (1981) is used to assess convergent validity, and for AVE, a threshold value of 0.5 is also suggested. Table 2 summarizes factor loading of retained indicators, composite scale reliability, and average variance extracted. Hulland (1999) suggests that an item is significant if its factor loading is greater than 0.7 to ensure construct validity. Adherence to this criterion required the modification of three scales through the removal of three items in transformational leadership, four items in organizational learning, and four items in organizational innovation. Because the factor loading was no more than 0.7 , the original items OL2, OL3, OL4, IS1, IM1, and OI5 were deleted, and then all items were rearranged. After the removal of the non-valid items, each item was revalidated by testing its item-to-total correlation measure, where all items had higher measures than the 0.35 threshold suggested by Saxe and Weitz (1982). All the measures had adequate reliability and validity. The development of each scale in this study was as follows.

\section{Transformational leadership}

Transformational leadership was measured using a 20-item composite scale comprised of items from MLQ 5X (Bass and Avolio 2006). All items were rated using a 5-point scale ranging from 1 ("Very strongly disagree") to 5 ("Very strongly agree"). Sample items included the following questions: "The leader got me to look at problems from many different angles" and "the leader expressed

Table 1 Index of confirmatory factor analysis

\begin{tabular}{lcll}
\hline Index & $\begin{array}{l}\text { Transformational } \\
\text { leadership (TL) }\end{array}$ & $\begin{array}{l}\text { Organizational } \\
\text { learning (OL) }\end{array}$ & $\begin{array}{l}\text { Organizational } \\
\text { innovation (OI) }\end{array}$ \\
\hline GFI & .897 & .996 & .996 \\
AGFI & $.865^{\text {a }}$ & .981 & .981 \\
RMR & .028 & .009 & .013 \\
RMSEA & .072 & .028 & .028 \\
NNFI(TLI) & .955 & .998 & .997 \\
CFI & .961 & .999 & .999 \\
$\chi^{2}$ & 315.487 & 2.526 & 2.499 \\
$d f$ & 117 & 2 & 2 \\
Normed & 2.696 & 1.263 & 1.250 \\
$\quad$ chi- & & & \\
square & & &
\end{tabular}

a means the value of AGFI is still acceptable
Table 2 Reliability of constructs $(\mathrm{N}=330)$

\begin{tabular}{|c|c|c|c|c|}
\hline Construct & Measure $^{\mathrm{a}, \mathrm{b}}$ & $\begin{array}{l}\text { Factor } \\
\text { loadings }\end{array}$ & $\begin{array}{l}\text { Composite } \\
\text { reliability } \\
\left(\rho_{\mathrm{c}}\right)\end{array}$ & $\mathrm{AVE}^{\mathrm{c}}$ \\
\hline \multirow{5}{*}{$\begin{array}{l}\text { Organizational } \\
\text { learning }\end{array}$} & & & .894 & .679 \\
\hline & OL1 & .717 & & \\
\hline & OL5 & .854 & & \\
\hline & OL6 & .842 & & \\
\hline & OL7 & .875 & & \\
\hline \multirow{22}{*}{$\begin{array}{l}\text { Transformational } \\
\text { leadership }\end{array}$} & IC & .921 & .894 & .678 \\
\hline & IC1 & .801 & & \\
\hline & IC2 & .790 & & \\
\hline & IC3 & .861 & & \\
\hline & IC4 & .840 & & \\
\hline & IIB & .998 & .849 & .653 \\
\hline & IIB1 & .802 & & \\
\hline & IIB2 & .848 & & \\
\hline & IIB4 & .772 & & \\
\hline & IIA & .951 & .923 & .749 \\
\hline & IIA1 & .840 & & \\
\hline & IIA2 & .915 & & \\
\hline & IIA3 & .875 & & \\
\hline & IIA4 & .829 & & \\
\hline & IS & .941 & .869 & .689 \\
\hline & IS2 & .859 & & \\
\hline & IS3 & .808 & & \\
\hline & IS4 & .823 & & \\
\hline & IM & .933 & .893 & .736 \\
\hline & IM2 & .851 & & \\
\hline & IM3 & .867 & & \\
\hline & IM4 & .856 & & \\
\hline \multirow{5}{*}{$\begin{array}{l}\text { Organizational } \\
\text { Innovation }\end{array}$} & & & .838 & .566 \\
\hline & OI1 & .782 & & \\
\hline & OI2 & .833 & & \\
\hline & OI3 & .735 & & \\
\hline & OI4 & .707 & & \\
\hline
\end{tabular}

a $O L$ Organizational leadership, IC Individual consideration, IIB Idealized influence (behavior), IIA = Idealized influence (attributed), $I S$ intellectual stimulation, $I M$ individual inspiration, $T L$ transformational leadership scale, $O I$ organizational innovation

b Because the factor loading was no more than 0.7 , the original items OL2, OL3, OL4, IS1, IM1, and OI5 were deleted, and then all items were rearranged

c $\mathrm{AVE}=\Sigma(\text { loading })^{2} /[\Sigma \text { (loading })^{2}+\Sigma($ variance $\left.)\right]$

confidence that goals would be achieved." Internal consistency was measured with Cronbach's alpha $(\alpha=.893)$. A five-factor model was confirmed after carrying out a confirmatory factor analysis (CFA), reflecting acceptable goodness-of-fit indexes and composite reliability $\left(\rho_{\mathrm{c}}\right)\left(\chi^{2} /\right.$ 
$d f=2.696<3$, GFI $=.897$, AGFI $=.865$, RMSEA $=$ $.072, \rho_{\mathrm{cIC}}=.894, \rho_{\mathrm{cIIB}}=.849, \rho_{\mathrm{cIIA}}=.923, \rho_{\mathrm{cIS}}=.869$, $\rho_{\mathrm{cIM}}=.893, \mathrm{AVE}_{\mathrm{IC}}=.678, \mathrm{AVE}_{\mathrm{IIB}}=.653, \mathrm{AVE}_{\mathrm{IIA}}=$ $\left..749, \mathrm{AVE}_{\mathrm{IS}}=.689, \mathrm{AVE}_{\mathrm{IM}}=.736\right)$.

\section{Organizational learning}

Organizational learning was measured by two items adapted from the scale of Kale, Singh and Perlmutter (2000), with an additional two items from Edmondson (1999) and three from García-Morales et al. (2006). All were rated using a 5-point scale ranging from 1 ("Very strongly disagree") to 5 ("Very strongly agree"). Sample items included the following questions: "The organization has acquired and used much new and relevant knowledge that has provided a competitive advantage over the last 3 years" and "The organization is a learning organization." Internal consistency was measured with Cronbach's alpha ( $\alpha=.893$ ). A one-factor model was confirmed and 3 items were deleted after a confirmatory factor analysis was carried out (CFA), reflecting acceptable goodness-of-fit indexes $\quad\left(\chi^{2} / d f=1.263, \quad\right.$ GFI $=.996, \quad$ AGFI $=.981$, RMSEA $=.028$, composite reliability $\left(\rho_{\mathrm{c}}\right)=.894, \mathrm{AVE}=$ .679).

\section{Organizational innovation}

Organizational innovation was measured by seven items adapted from Friedman (2003). All items were rated using a 5-point scale ranging from 1 ("Very strongly disagree") to 5 ("Very strongly agree"). Sample items include the following questions: "Teachers often introduce new ideas for school improvement and change" and "The school administration encourages teachers to seek new direction and challenges in teaching." It was suggested that one item be removed from the OIS (Organizational Innovation Scale) on the basis of an exploratory factor analysis (EFA), due to high structure coefficient loading above 1 (Hair et al. 2010). In this study, a 5-point scale (ranging from 1, "Very strongly disagree" to 5, "Very strongly agree") was used. Cronbach's alpha reflected a good level of internal consistency $(\alpha=.835)$. A CFA one-factor model test gave good goodness-of-fit indexes $\left(\chi^{2} / d f=1.250, \mathrm{GFI}=.996\right.$, $\left.\mathrm{AGFI}=.981, \mathrm{RMSEA}=.013, \rho_{\mathrm{c}}=.838, \mathrm{AVE}=.566\right)$.

\section{Data analysis}

Questionnaires were inspected and processed in order to exclude copies with incomplete answers. Valid copies were then assigned numbers and filed. The computer software used for data analysis and processing was SPSS 15.0 and AMOS 7.0 (Analysis of Moment Structures). The tests included reliability analysis, descriptive statistics analysis, and structural equation modeling (SEM). AMOS 7.0 was primarily used for SEM in this study to assess relationships across various dimensions. According to Jöreskog and Sörbom (1999), structural equation modeling allows not only the determination of relationship extent between variables but also the examination of the chain of cause and effect. This means that the results do not merely show empirical relationships between variables when defining the practical situation. This study utilized structural equation modeling to test the hypotheses as well as the ratio of Chi-square, goodness-of-fit index (GFI), adjusted goodness-of-fit index (AGFI), normal fit index (NFI), and root mean square residual (RMSR) to evaluate overall model fitness.

\section{Results}

Correlation between the measures

The Pearson's correlation coefficients among the variables are presented in Table 3. There were links between transformational leadership, organizational learning, and organizational innovation for all participants. It shows the means, standard deviations, correlations, and alpha coefficients of the measures. It can be seen that transformational leadership is significantly and positively correlated with organizational learning $(r=.689, p<.001)$ and with organizational innovation $(r=.574, p<.001)$. Organizational learning has significant positive correlation with organizational innovation $(r=.621, p<.001)$. There was significant correlation between many of the variables, but this was less than .70 .

Positive and significant relationships were also found between transformational leadership, organizational learning, and organizational innovation for all participants (see Table 4). Transformational leadership subscales correlated as expected. Organizational learning and organizational innovation were positively correlated with the other transformational leadership subscales. The transformational leadership subscales (IS, intellectual stimulation; IIB, idealized influence (behavior); IIA, idealized influence

Table 3 Means, standard deviations, correlations, and alpha coefficients $(\mathrm{N}=330)$

\begin{tabular}{llllll}
\hline Variable & $\mathrm{M}$ & $\mathrm{SD}$ & $\mathrm{TL}$ & $\mathrm{OL}$ & $\mathrm{OI}$ \\
\hline $\begin{array}{l}\text { Transformational leadership } \\
\quad 3.84\end{array}$ & .63 & $(.968)$ & & \\
$\quad(\mathrm{TL})$ & & & & & \\
Organizational learning (OL) & 3.82 & .62 & $.689 * * *$ & $(.893)$ & \\
$\begin{array}{l}\text { Organizational innovation } \\
\quad 3.57\end{array}$ & .45 & $.574 * * *$ & $.621 * * *$ & $(.835)$ \\
$(\mathrm{OI})$ & & & & & \\
\hline
\end{tabular}

$* * * p<.001$ 
Table 4 Inter-correlation among the transformational leadership scale and subscales, organizational learning, and organizational innovation $(\mathrm{N}=330)$

$* * * p<.001$

\begin{tabular}{llllllll}
\hline & TL & OL & OI & IS & IIB & IIA & IM \\
\hline OL & $.689 * * *$ & & & & & & \\
OI & $.574 * * *$ & $.621 * * *$ & & & & & \\
IS & $.890 * * *$ & $.653 * * *$ & $.568 * * *$ & & & & \\
IIB & $.918 * * *$ & $.620 * * *$ & $.513 * * *$ & $.757 * * *$ & & & \\
IIA & $.932 * * *$ & $.633 * * *$ & $.519 * * *$ & $.768 * * *$ & $.844 * * *$ & & \\
IM & $.914 * * *$ & $.580 * * *$ & $.467 * * *$ & $.752 * * *$ & $.805 * * *$ & $.838 * * *$ & \\
IC & $.907 * * *$ & $.660 * * *$ & $.554 * * *$ & $.791 * * *$ & $.775 * * *$ & $.804 * * *$ & $.768 * * *$ \\
\hline
\end{tabular}

(attributed); IM, individual inspiration, and IC, individual consideration) are distinct factors (Bass and Avolio 2006). A composite score of the organizational learning and organizational innovation was created for the subsequent test of the causal model due to the high correlation of the transformational leadership subscales. All the transformational leadership subscales were positively related to organizational learning and organizational innovation.

\section{Model and analysis}

The AMOS 7.0 maximum likelihood program was used to test the theoretical model. The hypothesized causal relationships between transformational leadership, organizational learning, and organizational innovation have been confirmed. The goodness-of-fit statistics shown in Table 5, include $\chi^{2}$ goodness-of-fit statistics, comparative fit index (CFI) (Bentler 1990), adjusted goodness-of-fit index (AGFI), and root mean square error of approximation (RMSEA). The fit indicators of the CFI and AGFI should be larger than .90 and the RMSEA less than .05 for a wellfitting model, and the fit is reasonable if the RMSEA is between .05 and .08. According to Browne and Cudeck (1993), the model is a good fit if the RMSEA is between .01 and .05. This study is based on Byrne (1998) and Bollen (1989) goodness-of-fit statistics. The composite score for transformational leadership included five observed variables: intellectual stimulation (IS), idealized influence (behavior) (IIB), idealized influence (attributed) (IIA), inspirational motivation (IM), and individual consideration (IC).

Table 5 shows the structural model with standardized coefficients for the research sample. The results provide sufficient support for $\mathrm{H}_{1}$. Results of the analysis revealed that transformational leadership is significantly and positively related to organizational innovation $\left(\gamma_{11}=.716\right.$, $p<.001)$. It can also be seen in Table $5\left(\mathrm{H}_{2}\right.$ and $\left.\mathrm{H}_{3}\right)$ that transformational leadership is significantly and positively related to organizational learning, $\gamma_{21}=.738, p<.001$ and organizational learning is significantly and positively related to organizational innovation, $\beta_{21}=.645, p<.001$.

Figure 2 illustrates the basis of the model proposed, together with the hypotheses to be contrasted. We used recursive non-structured models, taking transformational leadership $\left(\xi_{1}\right)$ as the exogenous latent variable and organizational learning $\left(\eta_{1}\right)$ and organizational innovation $\left(\eta_{2}\right)$ as the endogenous latent variables. Through a flexible interplay between theory and data, this structural equation model approach bridges theoretical and empirical knowledge for a better understanding of the real world (Raftery 1995). Such analysis allows for modeling based on both latent and manifest variables, a property well suited for the hypothesized model where most of the represented constructs are abstractions of unobservable phenomena. Furthermore, a structural equation model takes into account errors in measurement and variables with multiple indicators.

However, path analysis was used in this study to show the direct and indirect effects of each construct. The results are shown in Table 6. Analysis reveals the significant direct effect of transformational leadership and organizational innovation $\left(\gamma_{\text {direct }}=.276, p<.001\right)$ and the indirect effect $\left(\gamma_{\text {indirect }}=.462, p<.001\right)$ can be seen in Fig. 2 . Table 5 shows that it is a good fit model. $\left(\chi^{2} / d f=\right.$ $1.640<2, \quad$ GFI $=.908, \quad$ CFI $=.976, \quad$ RMSEA $=.013$, $\mathrm{RMR}=.025, \quad \mathrm{TLI} \quad(\mathrm{NNFI})=.972, \quad \mathrm{CN}=231>200$,

Table 5 Results of the structural parameter estimates and goodness-of-fitness indexes

\begin{tabular}{|c|c|c|c|c|}
\hline Hypotheses & Paths & Standardized coefficients & $t$ value & Result \\
\hline $\mathrm{H}_{1}$ & Transformational leadership $\rightarrow$ Organizational innovation $\left(\gamma_{11}\right)$ & .716 & $4.443 * * *$ & Supported \\
\hline $\mathrm{H}_{2}$ & Transformational leadership $\rightarrow$ Organizational learning $\left(\gamma_{21}\right)$ & .738 & $12.183 * * *$ & Supported \\
\hline $\mathrm{H}_{3}$ & Organizational learning $\rightarrow$ Organizational innovation $\left(\beta_{21}\right)$ & 645 & $8.805 * * *$ & Supported \\
\hline
\end{tabular}




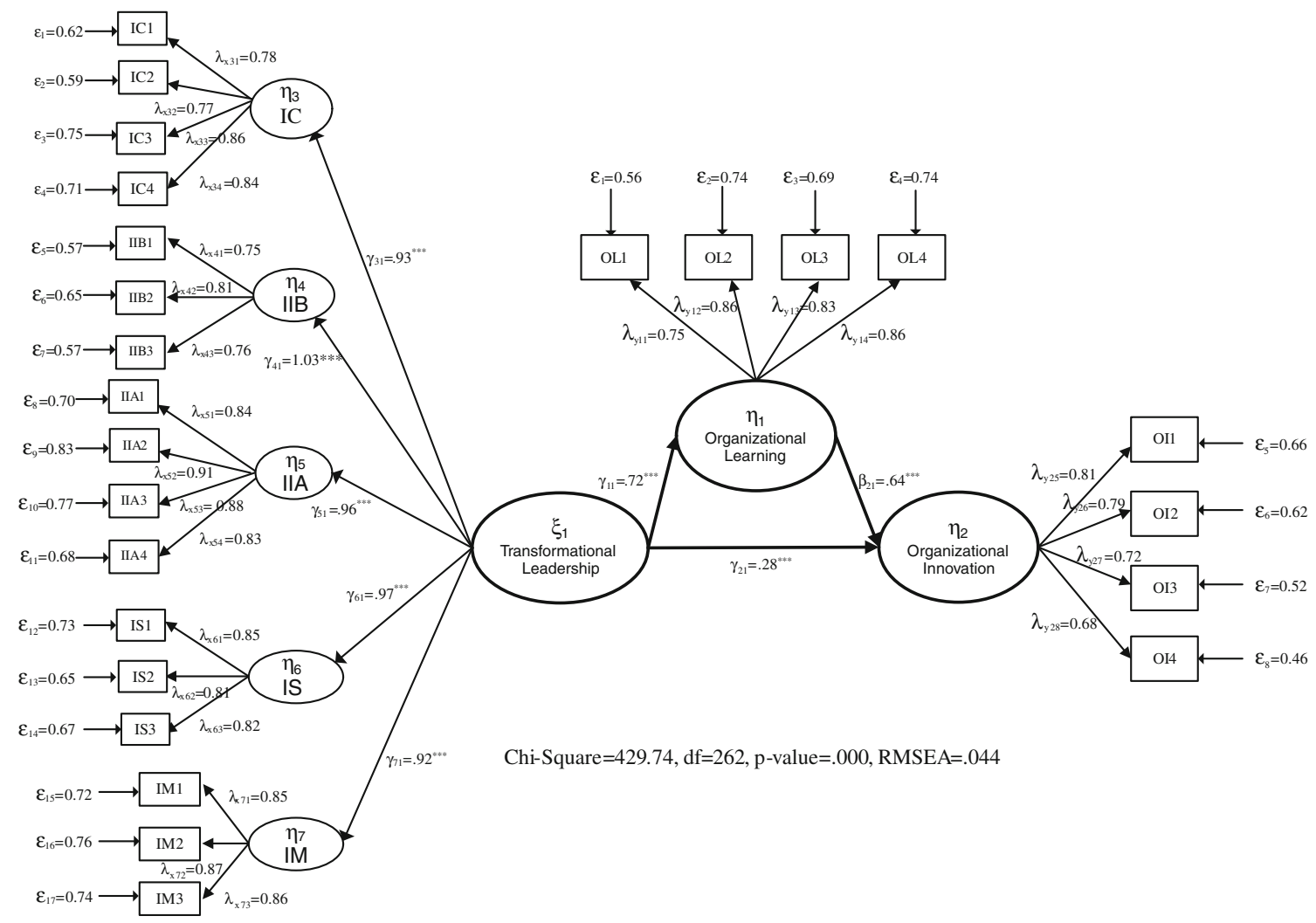

Fig. 2 Results of structural equation model

Table 6 Direct and indirect relationship

\begin{tabular}{|c|c|c|c|c|}
\hline \multirow[t]{2}{*}{ Variables } & \multicolumn{4}{|l|}{ Endogenous } \\
\hline & $\begin{array}{l}\text { Organizational } \\
\text { learning }\end{array}$ & $t$ value & $\begin{array}{l}\text { Organizational } \\
\text { innovation }\end{array}$ & $t$ value \\
\hline \multicolumn{5}{|l|}{ Exogenous } \\
\hline \multicolumn{5}{|c|}{ Transformational leadership } \\
\hline Direct & $.716^{* * *}$ & 12.183 & $.276 * * *$ & 4.443 \\
\hline Indirect & - & & $.462 * * *$ & 7.437 \\
\hline Total & $.716^{* * *}$ & & $.738 * * *$ & 10.075 \\
\hline \multicolumn{5}{|c|}{ Organizational Learning } \\
\hline Direct & & & $.645^{* * *}$ & 8.805 \\
\hline Indirect & & & - & - \\
\hline Total & & & $.645^{* * *}$ & 8.805 \\
\hline
\end{tabular}

innovation results from significant changes in organizational learning. It appears that organizational innovation will result if the organization members support organizational learning.

\section{Conclusion and implications}

The implications of theory

The main purpose of this study was to examine the mediating effect of organizational learning on
The result reveals that more organizational learning leads to more organizational innovation. Organizational 
transformational leadership and organizational innovation. The results reveal that when secondary high school principals used strategies such as transformational leadership and organizational learning, organizational learning was a highly effective influence for the achievement of organizational innovation. School principals play the major role in organizational innovation. Principals have important responsibilities and should lead their teachers in making changes at schools. They should also discuss the importance of organizational change (that is innovation) in the school system with them (Kursunoglu and Tanriogen 2009). Czarnitzki and Kraft (2004) proposed a causal model of transformational leadership as an important influence on organizational innovation. Furthermore, Cohen and Levinthal (1990) pointed out that the leaders should use organizational learning to promote organizational innovation. As the studies of Liao and $\mathrm{Wu}$ (2010) and McKee (1992) show, organizational learning is significantly and positively related to organizational innovation. Weerawardena et al. (2006) also found that the more organizational learning, the more organizational innovation. This study is in full support of the findings of these previous studies.

In this study, it emerged that if principals adhere to transformational leadership and do not use the strategy of organizational learning; this will have little impact on organizational innovation. As a result of increasingly rapid innovation, schools need to change in order to survive and be effective (Kursunoglu and Tanriogen 2009). The effect of transformational leadership, without the strategy of organizational learning, is insufficient. Furthermore, the indirect effect of organizational learning is bigger than the direct effect of transformational leadership on organizational innovation. These findings are supported by the SEM analysis of this model, and it is clear that transformational leadership has a positive influence on organizational innovation. This finding is consistent with the research by Dionne et al. (2004). Gumusluoglu and Ilsev (2009) also found that encouraging leaders to engage in transformational leadership behavior promoted organizational innovation. Both public and private school principals occupy positions which are very similar to those of company CEOs and directors. Principals and teachers in charge of the administration in schools devote themselves to seeking more effective management. To be excellent, school principals must also have excellent leadership and management. As Dess and Picken (2000) have emphasized, the 21 st century environment will require organizations to continuously innovate by harnessing the collective knowledge, skills, and creative efforts of their employees. Transformational leadership can be an effective part of the response. To our knowledge, this study is the first in which transformational leadership has been associated with organizational learning and innovation from a macro-level perspective.

To summarize, this study makes several contributions to research on transformational administration. The first being is that organizational learning mediates the relationship between transformational leadership and organizational innovation. It reveals the indirect effect of transformation leadership, which, through organizational learning, influences organizational innovation more than the direct effect of transformational leadership. Secondly, the findings of this study support previous work, including that of Jung et al. (2003), who found that transformational leadership had a significant positive influence on organizational innovation. Thirdly, organizational learning has a positive and significant effect on organizational innovation. This study supports and confirms the mediator role of organizational learning. In other words, organizational learning triggers the relationship between transformational leadership and organizational innovation. Higher organizational learning more easily leads to better organizational innovation. This finding is consistent with the work of Liao et al. (2008). Organizational innovation still relies on organizational learning to develop innovative strategies and performance.

\section{Practical implications}

Current and previous studies on innovation from the teachers' perspective (e.g., Zhang 2009; Hsiao et al. 2009; Somech 2010) highlight the importance of organizational innovation-specific meaning in a school and its association with actual innovational behavior. Our findings suggest that it is beneficial to organizational innovation to encourage organizational learning through means other than just increasing the teachers' belief in their innovational contributions and their principals' transformational leadership. An organization may encourage organizational innovation by facilitating an increased understanding and appreciation of the instrumentality of organizational learning for collective functionality and effectiveness. More specifically, incorporating case illustrations and research evidence in orientation and training may help teachers recognize the important of organizational learning and directly motivate them to innovate. Our findings suggest that organizations may also innovate by recruiting principals or division supervisors who have potential for constructive transformational leadership as a means to facilitate perceived organizational and individual instrumentalities and organizational innovation. Other practical consideration may involve the use of competency modeling practices to incorporate organizational innovation, signal the importance of this type of behavior, and encourage maximum performance (Sanchez and Levine 2009). 


\section{Limitations and further suggestions}

Although we have found several encouraging results, it is important to recognize that the current findings of this study include some limitations that suggest further empirical research would be useful. First, this study only examined transformational leadership, organizational learning, and organizational innovation. An investigation of other variables, not included in this study, such as organizational culture, leader-member exchange, support for innovation, and so on might be profitable. Future studies should be based preferably on these variables.

The second limitation of this study is related to the measurement of the five dimensions of transformational leadership by MLQ $(5 \times)$. In fact, MLQ $(5 \times)$ measures nine single-order leadership factors, transformational, transactional, and non-leadership styles (Bass and Avolio 2006). The five transformational leadership factors were: idealized influence attributes, idealized influence behavior, inspirational motivation, intellectual stimulation, and individualized consideration. The three transactional factors were: contingent reward, active management by exception, and passive management by exception. One non-transactional factor was included, laissez-faire leadership. Therefore, this study suggests that future research may also examine additional leadership behavior such as transactional and non-transactional factors.

Thirdly, common method variance could be an issue as data on the predictor and criterion variables were collected from the same source. However, we controlled this potential problem with the Harman's one-factor test and examined the un-rotated factor solution (Podsakoff et al. 2003). Results of the EFA demonstrated that no single factor accounted for the majority of the covariance among the measures. Because a single factor did not emerge, and Factor 1 did not explain most of the variance, common method bias in our data was unlikely to have been of concern.

The final limitation concerns the self-report surveys. In this study, a self-report was used to measure the results which could be limited by a socially desirable response. Because of the likelihood that such responses would lead to common method variance and inflation correlations between the self-report measures (Chan 2007) given that the respondents in this study were not engaged in high stakes testing. Therefore, possible future study should expand the sample size. In addition, the sample selected in this study was from educational managers in the secondary schools in Taiwan. Future studies should expand the sample to include more subjects or can be conducted with a collection of more samples in different levels or groups, e.g., students and their parents, and then the results will turn out to be persuasive.
The purpose of this study was to understand and examine the mediation effects and real relationships between transformational leadership, organizational learning, and organizational innovation. Future research may include identifying the specific factors that either lead to or increase organizational innovation.

Acknowledgments This study was supported by the National Science Council, Taiwan, R.O.C., under Grant NSC96-2516-S-027-001MY3.

Open Access This article is distributed under the terms of the Creative Commons Attribution Noncommercial License which permits any noncommercial use, distribution, and reproduction in any medium, provided the original author(s) and source are credited.

\section{References}

Aragón-Correa, J. A., García-Morales, V. J., \& Cordón-Pozo, E. (2007). Leadership and organizational learning's role on innovation and performance: lessons from Spain. Industrial Marketing Management, 15(5), 403-422.

Argyris, C., \& Schön, D. A. (1978). Organization learning: A theory of action perspective. Reading: Addison-Wesley.

Bass, B. M., \& Avolio, B. J. (2006). Multifactor leadership questionnaire technical report. Thousand Oaks: Sage.

Bentler, P. M. (1990). Comparative fit indexes in structural models. Psychological Bulletin, 107, 238-246.

Bollen, K. A. (1989). Structural equations with latent variables. New York: Wiley.

Browne, M. W., \& Cudeck, R. (1993). Alternative ways of assessing model fit. In K. A. Bollen \& J. S. Long (Eds.), Testing structural equation models (pp. 136-162). Newbury Park: Sage.

Byrne, B. M. (1998). Structural equation modeling with LISREL, PRELIS, and SIMPLIS: basic concepts, applications, and programming. Mahwah: Erlbaum.

Chan, D. (2007). Truths and myths in the problem of self-report data. Workshop conducted at the Seventh Industrial and Organizational Psychology Conference/First Asia Pacific Congress on Work and Organizational Psychology. Australia: Adelaide.

ChanLin, L., Hong, J., Horng, J., Chang, S., \& Chu, H. (2006). Factors influencing technology integration in teaching- a Taiwanese perspective. Innovations in Education and Teaching International, 43(1), 57-68.

Chen, L. Y. (2002). An examination of the relationship between leadership behavior and organizational commitment at steel companies. Journal of Applied Management and Entrepreneurship, 7, 122-142.

Cohen, W. M., \& Levinthal, D. A. (1990). Absorptive capacity: A new perspective on learning and innovation. Administrative Science Quarterly, 35(1), 128-152.

Czarnitzki, D., \& Kraft, K. (2004). Firm leadership and innovative performance: Evidence form seven EU countries. Small Business Economics, 22, 325-332.

Davies, B. (Ed.) (2005). The essentials of school leadership. London: Paul Chapman.

Dess, G. G., \& Picken, J. C. (2000). Changing roles: Leadership in the 21st century. Organizational Dynamics, 29(4), 18-33.

Dionne, S. D., Yammarino, F. J., Atwater, L. E., \& Spangler, W. D. (2004). Transformational leadership and team performance. 
Journal of Organizational Change Management, 17(2), 177-193.

Edmondson, A. C. (1999). Psychological Safety and learning behavior in work teams. Administrative Science Quarterly, 44, 350-394.

Elkins, T., \& Keller, R. T. (2003). Leadership in research and development organizations: A literature review and conceptual framework. Leadership Quarterly, 14, 587-606.

Fidler, B. (2003). Strategic management for school development. London: Paul Chapman.

Fornell, C., \& Larcker, D. (1981). Structural equation models with unobservable variables and measurement error. Journal of Marketing Research, 18(1), 39-50.

Friedman, I. A. (2003). School organizational values: The driving force for effectiveness and chang. In P. T. Begley \& O. Johansson (Eds.), The ethical dimensions of school leadership (pp. 161-179). Netherlands: Kluwer Academic Publishers.

García-Morales, V. J., López-Martin, F. J., \& Llamas-Sánchez, R. (2006). Strategic factors and barriers for promoting educational organizational learning. Teaching \& Teacher Education, 22(4), 478-502.

García-Morales, V. J., Lloréns-Montes, F. J., \& Verdú-Jover, A. J. (2008). The effects of transformational leadership on organizational performance through knowledge and innovation. British Journal of Management, 19, 299-319.

Gerybadze, A., \& Reger, G. (1999). Globalization of R\&D: recent changes in the management of innovation in transnational corporations. Research Policy, 28(2-3), 251-274.

Gumusluoglu, L., \& Ilsev, A. (2008). Transformational leadership, creativity, and organizational innovation. Journal of Business Research, 62(4), 461-473.

Gumusluoglu, L., \& Ilsev, A. (2009). Transformational leadership and organizational innovation: The roles of internal and external support for innovation. Journal of Product Innovation Management, 26(3), 264-277.

Hair, J. F., Black, W. C., Babin, B. J., \& Anderson, R. E. (2010). Multivariate data analysis: A global perspective (7th ed.). Upper Saddle River: Pearson Prentice Hall.

Hecker, L., \& Birla, R. K. (2008). Intangible factors leading to success in research: Strategy, innovation and leadership. Journal of Cardiovascular Translational Research, 1, 85-92.

Howell, J. M., \& Higgins, C. A. (1990). Champions of change: Identifying, understanding, and supporting champions of technological innovation. Organizational Dynamics, 19, 40-55.

Hsiao, H. C., Chang, J. C., \& Tu, Y. L. (2009). The Influence of the Transformational Leadership and Organizational Learning on Organizational Innovation for Electrical and Electronic Cluster of Vocational High School Teachers: a Taiwanese Perspective. Proceedings of 2009 International Conference on Social Science and Humanities, pp. 146-150. Singapore, 9-11 October, 2009.

Hsiao, H. C., Chen, M. N., \& Yang, H. S. (2008). Leadership of vocational high school principals in curriculum reform: a case study in Taiwan. International Journal of Educational Development, 28, 669-686.

Hulland, J. (1999). Use of partial least squares (PLS) in strategic management research: a review of four recent studies. Strategic Management Journal, 20(2), 195-204.

Jöreskog, K. G., \& Sörbom, D. (1999). LISREL 8.30: User's reference guide. Chicago: Scientific Software International.

Jung, D. I., Chow, C., \& Wu, A. (2003). The role of transformational leadership in enhancing organizational innovation: Hypotheses and some preliminary findings. The Leadership Quarterly, 14, 525-544.

Jung, D. I., \& Sosik, J. (2002). Transformational leadership in work groups: The role of empowerment, cohesiveness, and collectiveefficacy on perceived group performance. Small Group Research, 33(3), 313-336.
Kale, P., Singh, J., \& Perlmutter, H. (2000). Learning and protection of assets in strategic alliance: Building Relationship Capital. Strategic Management Journal, 21(3), 217-237.

Kark, R., Shamir, B., \& Chen, G. (2003). The two faces of transformational leadership: Empowerment and dependency. Journal of Applied Psychology, 2, 246-255.

Keller, R. T. (1992). Transformational leadership and the performance of research and development project groups. Journal of Management, 18, 489-501.

Kursunoglu, A., \& Tanriogen, A. (2009). The relationship between teachers' perceptions towards instructional leadership behaviors of their principals and teachers' attitudes towards change. Procedia Social and Behavioral Sciences, 1(1), 252-258.

Lei, D., Slocum, J. W., \& Pitts, R. A. (1999). Designing organizations for competitive advantage: the power of unlearning and learning. Organizational Dynamics, 27(3), 24-38.

Liao, S. H., Fei, W. C., \& Liu, C. T. (2008). Relationship between knowledge inertia, organizational learning, and organizational innovation. Technovation, 28, 183-195.

Liao, S. H., \& Wu, C. C. (2010). System perspective of knowledge management, organizational learning, and organizational innovation. Expert Systems with Applications, 37(2), 1096-1103.

Lloréns Montes, F. J., Ruiz Moreno, A., \& García Morales, V. (2005). Influence of support leadership and teamwork cohesion on organizational learning, innovation and performance: An empirical examination. Technovation, 25, 1159-1172.

Louis, K. S. (2006). Change over time? An introduction? A reflection? Educational Administration Quarterly, 42(1), 165-173.

McGill, M. E., \& Slocum, J. W. (1993). Unlearning the organization. Organizational Dynamic, 22(2), 67-79.

McKee, D. (1992). An organizational learning an approach to product innovation. Journal of Product Innovation Management, 9, 232-245.

Michael, D. M., Steven, J. K., \& Charnchai, T. (2004). The effects of performance and team cohesion on attribution: a longitudinal simulation. Journal of Business Research, 57, 1108-1115.

Ministry of Education. (2003). White paper on creative education. Taipei: Author.

Montes, F. J. L., Moreno, A. R., \& Morales, V. G. (2005). Influence of support leadership and teamwork cohesion on organizational learning, innovation and performance: An empirical examination. Technovation, 25(10), 1159-1172.

Podsakoff, P. M., MacKenzie, S. M., Lee, J., \& Podsakoff, N. P. (2003). Common method variance in behavioral research: A critical review of the literature and recommended remedies. Journal of Applied Psychology, 88, 879-903.

Raftery, A. E. (1995). Bayesian model selection in social research. In P. V. Marsden (Ed.), Sociological methodology (pp. 111-163). Cambridge: Basil Blackwell.

Robbins, P. S., \& Judge, A. T. (2009). Organizational behavior (13th ed.). Singapore: Pearson Prentice Hall.

Sanchez, J. I., \& Levine, E. D. (2009). What is (or should be) the difference between competency modeling and traditional job analysis? Human Resource Management Review, 19, 53-63.

Sarros, J. C., Tanewski, G. A., Winter, R. P., Santora, J. C., \& Densten, I. L. (2002). Work alienation and organizational leadership. British Journal of Management, 13, 285-304.

Saxe, R., \& Weitz, B. A. (1982). The SOCO Scale: A measure of the customer orientation of salespeople. Journal of Marketing Research, 19, 343-351.

Senge, P. M. (1990). The fifth discipline. New York: Doubleday.

Silins, H. C., Mulford, W. R., \& Zarins, S. (2002). Organizational learning and school change. Educational Administration Quarterly, 38(5), 613-642.

Slater, S. F., \& Narver, J. C. (1995). Market orientation and the learning organization. Journal of Marketing, 59, 63-74. 
Somech, A. (2010). Participative decision making in schools: A mediating-moderating analytical framework for understanding school and teacher outcomes. Educational Administration Quarterly, 46(2), 174-209.

Spender, J. C., \& Grant, R. M. (1996). Knowledge and the firm. Strategic Management Journal, 17, 5-9.

Swiering, J., \& Wierdsma, A. (1992). Becoming a learning organization: Beyond the learning curve. Addison-Wesley: Reading.

Tushman, M. L., \& Nadler, D. A. (1986). Organization for innovation. California Management Review, 28(3), 74-92.

Webber, S. S., \& Donahue, L. M. (2001). Impact of highly and less job- related diversity on work group cohesion and performance: a meta-analysis. Journal of Management, 27, 141-162.
Weerawardena, J., O'Cass, A., \& Julian, C. (2006). Does industry matter? Examining the role of industry structure and organizational learning in innovation and brand performance. Journal of Business Research, 59, 37-45.

Woodman, R. W., Sawyer, J. E., \& Griffin, R. W. (1993). Toward a theory of organizational creativity. Academy of Management, $18(2), 293-321$.

Yukl, G. (2002). Leadership in Organizations. Upper Saddle River: Prentice Hall.

Zhang, J.-W. (2009). Technology-supported learning innovation in cultural contexts. Education Technology Research \& Development, 58, 229-243. 